\title{
Enhanced fetal growth in sheep administered progesterone during the first three days of pregnancy
}

\author{
D. O. Kleemann ${ }^{1}$, S. K. Walker ${ }^{1 *}$ and R. F. Seamark ${ }^{2}$ \\ ${ }^{1}$ South Australian Research and Development Institute, Turretfield Research Centre, Rosedale, SA 5350 , \\ Australia; and ${ }^{2}$ Department of Obstetrics and Gynaecology, University of Adelaide, Adelaide, SA 5005, \\ Australia
}

Two experiments were conducted to determine whether administration of progesterone during early pregnancy affects fetal growth in sheep and if any effect is specific to the days of treatment. In the first experiment, Merino ewes were randomly allocated to four treatment groups and inseminated at a synchronized oestrus. Three groups received progesterone on days $1-3,3-6$ or 1-6 of pregnancy while the fourth group was untreated. Concentrations of progesterone in peripheral plasma increased $(P<0.05)$ in all treatment groups. Fetal growth (to day 74 ) was greater in all treatment groups than in the control group $(P<0.001)$ and was greatest when treatments started on day 1 . Pregnancy rate was not affected by progesterone treatment on days $3-6$, but was reduced $(P<0.05)$ when treatment began on day 1 . In the second experiment, embryos that had been exposed to either a normal (control) or a high concentration of progesterone on days 1-3 were randomly transferred, within groups, to recipient ewes that had or had not been treated with progesterone on days 1-3. In another group, embryos were exposed to a high concentration of progesterone on days I-3 and the oviducts of the ewe were ligated. An increase in fetal mass was observed in the recipient group that had been treated with progesterone $(P<0.01)$ but was not observed in the initial group treated with progesterone. A greater fetal mass was also obtained when embryos that had been ligated in the oviducts of ewes treated with progesterone $(P<0.05)$ were transferred. This effect occurred irrespective of whether the final recipients received progesterone. These findings indicate that progesterone supplementation to ewes during the first 3 days of pregnancy enhances the growth of surviving fetuses. It is concluded that progesterone treatment or ligation of the oviducts during the first three days of pregnancy induce changes in embryo development that affect subsequent development.

\section{Introduction}

There is evidence that changes in the environment of the preimplantation embryo can affect subsequent development. For example, the transient exposure of sheep embryos for 3 days to conditions in the uterus at later stages of pregnancy resulted in larger fetuses compared with control fetuses when measured on day 37 of pregnancy (Wilmut and Sales, 1981). Similarly, subjecting sheep zygotes to culture in vitro for 3-5 days (Walker et al., 1992a, b) or transferring bovine nuclei to host oocytes (Willadsen et al., 1991) resulted in progeny of higher than normal birth mass. Administration of progesterone to cows at days 1-4 of pregnancy enhanced fetal development (measured on day 14) compared with that observed in control animals (Garrett et al., 1988). In all these studies, changes to the embryo or to the environment of the embryo occurred within the first few days of development, highlighting the significance of this period on subsequent fetal development.

*Correspondence and reprint requests.

Revised manuscript received 12 May 1994.
The aim of this study was to define and explain how fetal development can be influenced by modification of the endocrine environment of the embryo. Specifically, the study aimed to examine (i) the effect of progesterone supplementation very early in pregnancy (days $1-3,3-6$ and $1-6$ inclusive) on fetal growth, (ii) whether any effect of progesterone on fetal growth was restricted to the days of treatment and (iii) whether any effect of progesterone depends on the exposure of embryos to the uterine environment during supplementation.

\section{Materials and Methods}

Animal experimentation was performed in accordance with the Australian Code of Practice for the Care and Use of Animals for Scientific Purposes and the Prevention of Cruelty to Animals Act 1985, after approval was granted by the Animal Ethics Committee of the South Australian Research and Development Institute. 


\section{Experiment 1}

Animals and experimental procedures. Two hundred mature South Australian Merino ewes, grazed on a clover/grass sward to maintain body condition, were treated with intravaginal progestagen pessaries $(60 \mathrm{mg}$ medroxyprogesterone acetate; Upjohn, Rydalmere) for 12 days and pregnant mares' serum gonadotrophin (PMSG: $400 \mathrm{iu}$; Heriot Agvet, Melbourne) was administered to each ewe when the pessary was removed. Merino rams (one ram per 10 ewes) were introduced to the ewes from the time of pessary removal and ewes were also inseminated with fresh semen directly into the uterus by laparoscopy (Killeen and Caffery, 1982) $51 \mathrm{~h}$ after the pessary was removed.

Experimental design and measurements. Controlled internal drug releasing (CIDR) progesterone pessaries $(300 \mathrm{mg}$ progesterone; Carter Holt Harvey Plastic Products, Hamilton) were inserted into two groups of ewes at either 36 (day 1) or $89 \mathrm{~h}$ (day 3) after ovulation. The median time of ovulation was assumed to be similar to that previously determined in South Australian Merino ewes that had been treated in the same way (Walker et al., 1989). Pessaries were removed on day 6. A third group received pessaries on day $I$ that were removed on day 3. A fourth group received no treatment (control).

A sample of ewes, chosen at random within treatments ( $n=6$ per treatment), were bled daily at $11: 00 \mathrm{~h}$ on days $2-7$ (control ewes and ewes treated on days 1-6), days 2-4 (ewes treated on days 1-3) or days 4-7 (ewes treated on days 3-6). On day 1 and day 3 , ewes were bled before the insertion of CIDR pessaries. Blood samples were centrifuged $(1500 \mathrm{~g}$, $15 \mathrm{~min}$ ) immediately after collection and plasma samples were stored at $-18^{\circ} \mathrm{C}$ before progesterone assay.

Progesterone concentrations were assayed by a direct ${ }^{125} \mathrm{I}$ radioimmunoassay (Farmos Diagnostica, Farmos Group, Turku) using charcoal-filtered sheep plasma as quality control. The progesterone antiserum has a negligible crossreactivity with other endogenous pregnen derivatives and related steroids. The recovery data on samples of $4.5 \mathrm{nmol} \mathrm{l}^{-1}, 9.1 \mathrm{nmol} \mathrm{l}^{-1}$ and $18.2 \mathrm{nmol} \mathrm{l}^{-1}$ were $100 \%, 99.0 \%$ and $97.3 \%$, respectively. The sensitivity of the assay was $0.5 \mathrm{nmol} \mathrm{I}^{-1}$. The intra-assay coefficients of variation over repeated measurements at concentrations of $6.4 \mathrm{nmol} \mathrm{l}^{-1}$ and $30 \mathrm{nmol} \mathrm{l}^{-1}$ were $7.4 \%$ and $9.5 \%$, respectively. Corresponding interassay coefficients of variation at similar concentrations were $16.6 \%$ and $10.0 \%$.

Litter size was assessed on day 71 of pregnancy using ultrasonography with a Microimager 1000 sector ultrasound scanner equipped with a $3.5 \mathrm{MHz}$ abdominal transducer (Ausonics, Sydney). All ewes were killed at a commercial abattoir on day 74 of gestation. The number of fetuses, and their sex, mass and crown-rump length were recorded.

Statistical analysis. Nine ewes were not inseminated owing to loss of pessaries, fat adhesions or physically abnormal reproductive tracts and these were omitted from the study. During the abattoir procedures, identification was lost from 2 , 4,4 and 2 ewes in the groups treated with progesterone on days $1-3,1-6,3-6$ and in the control group, respectively. The number of fetuses recorded for these ewes on day 74 was assumed to be the number determined by ultrasonography on day 71. The effect of treatment on pregnancy rate and the distribution of litter size was examined using the categorical model (CATMOD) procedure in SAS (Stanish and Sall, 1985). Continuous variables (progesterone concentration, fetal mass and fetal crown-rump length) were tested by the general linear model (GLM) procedure in SAS (Spector et al., 1985) using treatment and sex as the main effects, their interaction term and litter size as a covariate.

\section{Experiment 2}

Treatment of animals. South Australian Merino ewes ( $n=120$; embryo donors) were treated for 12 days with intravaginal progestagen pessaries and $17 \mathrm{mg}$ FSH (ScheringPlough Animal Health, Kenilworth, NJ). FSH was administered as five injections $(5,4,3,3$ and $2 \mathrm{mg}$ at approximately $12 \mathrm{~h}$ intervals) beginning $48 \mathrm{~h}$ before pessary removal. Synthetic GnRH ( $25 \mu \mathrm{g}$ per ewe: Intervet; Artarmon, NSW) was administered $27 \mathrm{~h}$ after completion of the progestagen treatment. Eight fertile rams were introduced to the ewes immediately after the progesterone pessary was withdrawn. In addition, ewes were inseminated directly into the uterus with approximately $20 \times 10^{\circ}$ frozen-thawed spermatozoa per uterine horn $45 \mathrm{~h}$ after removal of the pessary. Ejaculates from three rams were pooled before each of the six inseminations; ejaculates from different rams were used on each occasion. Recipient animals $(n=258)$ were treated with progestagen pessaries for 12 days and received PMSG (400 iu) when the pessary was removed. Vasectomized rams fitted with harnesses and marker crayons were introduced to the ewes at this time. Recipients were treated so that they were synchronous $( \pm 12 \mathrm{~h}$ ) with either donor animals or other recipient animals as required.

Embryo collection and transfer procedures. Zygotes were collected approximately $12-17 \mathrm{~h}$ after the expected median time of ovulation as determined by Walker et al. (1986). A Tom Cat catheter (Sherwood Medical, St Louis, MO) was inserted into the fimbriated end of the oviduct and $10 \mathrm{ml}$ PBS (Flow Laboratories, North Ryde, NSW) supplemented with 5\% heat inactivated sheep serum were flushed through each oviduct via a puncture in the uterine wall distal to the utero-tubular junction. Zygotes recovered from the flushings were stored in PBS for up to $1 \mathrm{~h}$ before they were transferred to initial recipient ewes by mid-ventral laparotomy. Zygotes were transferred in groups of 6-38 per ewe to an oviduct ipsilateral to an ovary containing at least one corpus luteum. Oviducts were ligated at the utero-tubal junction before transfer in one treatment group.

Embryos were recovered from initial recipients 3 days after transfer by mid-ventral laparotomy. A Foley catheter (IO FG, $3 \mathrm{ml}$ balloon; Sherwood Medical) was inserted into the appropriate uterine horn and the oviduct and uterine horn flushed with a total of $20 \mathrm{ml}$ PBS. Recovery of embryos from ligated oviducts followed a procedure similar to that described for the initial collection of zygotes. Embryos were then transferred (two per ewe) to the uterine horns of final recipients. Both embryo collection and transfer procedures were conducted under general anaesthesia induced by $10 \%(\mathrm{w} / \mathrm{v})$ thiopentane sodium (Pentothal: Boehringer Ingelheim, Artamon, NSW) 
Table 1. Progesterone concentrations (nmol $\mathrm{l}^{-1}$ ) in peripheral plasma of ewes treated with exogenous progesterone during days 1-6 after ovulation

\begin{tabular}{|c|c|c|c|c|c|c|c|c|}
\hline \multirow[b]{2}{*}{ Treatment } & \multirow[b]{2}{*}{$n$} & \multicolumn{7}{|c|}{ Day after ovulation } \\
\hline & & 1 & 2 & 3 & 4 & 5 & 6 & 7 \\
\hline Control & 6 & $1.4 \pm 0.3^{\mathrm{a}}$ & $2.4 \pm 0.7^{\mathrm{a}}$ & $2.7 \pm 0.9^{\mathrm{a}}$ & $3.5 \pm 1.1^{\mathrm{a}}$ & $3.8 \pm 1.2^{\mathrm{a}}$ & $6.2 \pm 1.9^{\mathrm{a}}$ & $7.1 \pm 1.7^{\mathrm{a}}$ \\
\hline \multicolumn{9}{|l|}{ Progesterone } \\
\hline days $1-3$ & 6 & $1.6 \pm 0.2^{\mathrm{a}}$ & $6.8 \pm 0.4^{b}$ & $8.4 \pm 0.8^{b}$ & $3.4 \pm 1.1^{\mathrm{a}}$ & - & - & - \\
\hline days $1-6$ & 6 & $1.6 \pm 0.2^{\mathrm{a}}$ & $7.0 \pm 0.4^{\mathrm{b}}$ & $8.4 \pm 0.8^{b}$ & $13.1 \pm 1.1^{\mathrm{b}}$ & $12.3 \pm 1.2^{b}$ & $18.2 \pm 1.9^{b}$ & $11.3 \pm 1.7^{\mathrm{a}}$ \\
\hline days $3-6$ & 6 & - & - & $4.5 \pm 0.7^{\mathrm{a}}$ & $11.3 \pm 1.1^{b}$ & $14.0 \pm 1.2^{b}$ & $20.3 \pm 1.9^{b}$ & $11.5 \pm 1.7^{\mathrm{a}}$ \\
\hline
\end{tabular}

Values are least-squares means \pm SEM.

Means within columns with different superscripts are significantly different $(P<0.05)$.

and maintained by a mixture of halothane (May and Baker, Dagenham) and oxygen.

Experimental design. The experiment was designed to expose embryos to either a normal (control) or a high progesterone environment during the first 3 days of pregnancy after which embryos in each group were transferred to either control ewes or ewes that had also been treated with progesterone on days 1-3. In an additional treatment group, the oviducts of initial recipient ewes treated with progesterone were ligated to prevent embryos migrating into the uterus during treatment.

Zygotes $(n=949)$ were transferred to the oviducts of initial recipient ewes ( $n=36$ ewes; six ewes per replicate) that were randomly allocated to either a control group (i.e. no progesterone treatment) or to a group treated with CIDRprogesterone pessaries for 3 days starting $13-18 \mathrm{~h}$ after the expected time of ovulation. In the latter group, the oviducts of 12 of 24 ewes were ligated. Progesterone pessaries were inserted at the time of embryo transfer. Embryos from each treatment group were recovered on day 3 and those containing four or more blastomeres were transferred to the uterine horns of final recipient ewes. Half of these ewes were also given progesterone pessaries. Therefore, the design was a $3 \times 2$ factorial (two levels of progesterone supplementation plus a progesterone treatment group with ligated oviducts in initial recipients; two levels of progesterone supplementation in final recipients).

Measurements. Initial recipient ewes from replicates 2, 4 and 6 ( $n=6$ ewes per treatment) were bled on day 3 before pessary withdrawal. Blood samples were centrifuged at $1500 \mathrm{~g}$ for $15 \mathrm{~min}$ immediately after collection and the plasma was stored at $-18^{\circ} \mathrm{C}$ before they were assayed for progesterone as previously described.

All recovered embryos were examined on day 3 and assessed ( $\times 40$ magnification) for number of blastomeres. Litter size was determined on day 50 of gestation using ultrasonography as previously described. Pregnant ewes were killed on day 76. The number of fetuses, fetal mass, fetal sex and crown-rump length were recorded.

Statistical analysis. Analysis of variance procedure (GLM in SAS; Spector et al., 1985) was used to interpret treatment effects on fetal mass and crown-rump length with a replicate included in the model as a variable factor. All first order interactions were tested initially and only those that were significant $(P<0.05)$ or that were of specific interest were included in the final model. Chi-square analysis (CATMOD procedure in SAS; Stanish and Sall, 1985) was used to test the effect of treatments on cleavage rate and the number of blastomeres per embryo (classified as $2-3,4-7,8-15, \geq 16$ ) at day 3 and number of fetuses at day 76 of gestation.

\section{Results}

\section{Experiment 1}

Progesterone concentrations in peripheral plasma of progesterone-treated groups were significantly higher $(P<0.05)$ than those of the control group on each day of treatment (Table 1).

Fetal growth was greater $(P<0.001)$ after all progesterone treatments compared with the control and was greatest in groups receiving progesterone from day 1 compared with day 3 (Table 2). Similar differences $(P<0.001)$ were observed for crown-rump length (Table 2 ), although in this case the control group and the group treated with progesterone on days 3-6 did not differ significantly.

Litter size varied significantly $(P<0.05)$ among treatments (Table 3). Progesterone treatments starting on day 1 resulted in $(P<0.05)$ a higher proportion of nonpregnant ewes compared with that obtained in the other groups. The number of fetuses per pregnancy did not differ among treatments.

\section{Experiment 2}

Progesterone concentrations in peripheral plasma were significantly $(P<0.05)$ higher after administration of progesterone between days 1 and 3 after ovulation; least squares means \pm SEM on day 3 were $6.9 \pm 1.2,19.7 \pm 1.2$ and $13.8 \pm 1.2 \mathrm{nmol}^{-1}$ for control, progesterone-treated and progesterone-treated plus oviduct ligature groups, respectively. There is no apparent reason for the significantly $(P<0.05)$ higher plasma progesterone concentration of ewes given progesterone compared with those treated with progesterone and subjected to oviduct ligation. The difference 
Table 2. The effect of progesterone treatment of ewes during early pregnancy on fetal mass and crown-rump length

\begin{tabular}{lcc}
\hline Treatment & Fetal mass $(\mathrm{g})$ & $\begin{array}{c}\text { Crown-rump } \\
\text { length }(\mathrm{mm})\end{array}$ \\
\hline Control & $220.8 \pm 3.2^{\mathrm{a}}$ & $204.0 \pm 1.1^{\mathrm{a}}$ \\
& $(139-269)$ & $(173-246)$ \\
Progesterone & $247.6 \pm 4.1^{\mathrm{b}}$ & $212.1 \pm 1.4^{\mathrm{b}}$ \\
days 1-3 & $(198-320)$ & $(199-232)$ \\
days 1-6 & $243.5 \pm 4.6^{\mathrm{b}}$ & $210.5 \pm 1.6^{\mathrm{b}}$ \\
& $(184-343)$ & $(194-229)$ \\
days 3-6 & $231.5 \pm 3.5^{\mathrm{c}}$ & $205.6 \pm 1.2^{\mathrm{a}}$ \\
& $(160-280)$ & $(160-225)$ \\
\hline
\end{tabular}

Values are least-squares means \pm SEM (range).

Means within columns with different superscripts are significantly different $(P<0.05)$.

in progesterone concentration between these treatments remained significant after ovulation rate was included in the analysis as a covariate.

Initial recipient, final recipient and sex main effects were significant sources of variation for fetal mass $(P \leq 0.05)$. These sources of variation were not statistically significant for crownrump length. There were no significant interactions between any of the main effects for either fetal mass or crown-rump length.

In the initial recipient, progesterone treatment alone did not result in greater fetal mass (Table 4) but ligation of the oviducts of ewes treated with progesterone did $(P<0.05)$. Progesterone treatment significantly $(P<0.01)$ increased fetal mass in the final recipient (Table 4).

The distribution of the number of blastomeres per embryo on day 3 differed significantly $(P<0.001)$ among treatment groups (Table 5). Embryo development was increased $(P<0.001)$ for the progesterone-treated group compared with the control group, whereas it was significantly $(P<0.001)$ retarded after progesterone treatment plus oviduct ligation. Furthermore, the number of putative zygotes that failed to cleave was significantly $(P<0.05)$ higher in the progesteronetreated group than in the other two groups.

Pregnancy rate was not significantly influenced by progesterone treatment in the initial recipient but was reduced $(P<0.001)$ by progesterone treatment in the final recipient (Table 6). There were no significant differences between treatments within both initial recipient and final recipient main effects for the number of fetuses per pregnancy.

\section{Discussion}

Fetal growth at mid-gestation was enhanced in ewes given progesterone during the first 3 days of pregnancy. This effect was not mediated during this period, but was a consequence of exposure of embryos to the progesterone-primed uterus thereafter. An exception to this finding occurred when the oviducts of treated ewes were ligated. However, it was not possible from the design of this study to determine whether the increased fetal growth observed after ligation resulted from progesterone treatment or from the effects of ligation per se.

The manner in which progesterone treatment influences fetal growth is not known, although it is well established that progesterone has an important role in mediating changes in the uterus necessary for development of the conceptus and placental attachment (Roberts and Bazer, 1988; Ashworth and Bazer, 1989). Garrett et al. (1988) demonstrated that progesterone treatment of cows on days 1-4 of pregnancy resulted in qualitative changes in polypeptide release during days 5-14, and increased bovine trophoblast protein-1 (bTP-1) at day 14 . These authors concluded that such changes may have directly or indirectly been responsible for increased conceptus development to day 14. However, Ashworth and Bazer (1989) administered progesterone to ewes on days 4-9 and noted quantitative changes in endometrial secretory proteins, but this was not associated with increased development of the conceptus. Uterine secretions were not examined in the current study, although results of preliminary studies using one-dimensional gel electrophoresis (Laemmli, 1970; Hochstrasser et al., 1988) indicate that progesterone treatment on days $1-3$ had minimal qualitative effects on the protein composition of uterine secretions between days 1 and 5 ( $\mathrm{K}$. Hartwich, unpublished). Growth factors involved with progesterone-mediated conceptus growth have not been clearly defined, although insulin-like growth factor I (IGF-I) and -II are present in the endometrium during the oestrous cycle. However, the time of rapid conceptus development is not associated with changes in these factors, although IGF-binding protein 2 appears to be regulated by progesterone between days 15 and 18 in cows (Geisert et al., 1991).

Progesterone treatment is known to accelerate the movement of embryos from the oviduct into the uterus (Day and Polge, 1968; Hunter, 1980; Crisman et al,, 1980). Thus, increases in fetal growth may be a consequence of perturbations in embryo migration. Premature migration of embryos into the uterus would be expected to result in an asynchrony between the physiological status of the progesterone-primed uterus and the developmental status of the embryo. Although it is known that the premature entry of embryos into the uterus is detrimental to laboratory animals (Chang, 1950) and livestock (Robinson, 1951; Moore and Shelton, 1964; Moore et al., 1983), the precise biochemical and physiological changes elicited by an asynchronous or unnatural environment are not known. When sheep embryos are exposed to an in vitro culture environment, lambs of unusually high birth mass may result following the transfer of cultured embryos to surrogate mothers (Walker et al., 1992a, b). These authors postulated that cytoplasmic fragmentation, frequently observed in cultured sheep embryos, may have affected the nuclear-cytoplasmic relationship during early embryogenesis with a resultant impact on fetal growth. Similar fragmentation may have occurred in the perturbed environment following progesterone treatment. The possibility that an asynchrony between the uterus and the embryo is responsible for the increased fetal growth is supported by the finding of Wilmut and Sales (1981). These authors exposed sheep embryos to an advanced uterine tract for 3 days followed by transfer to a second recipient synchronous with the original donor. Although the number of fetuses within treatment groups was small $(n<11)$ and embryo 
Table 3. The effect of progesterone treatment of ewes during early pregnancy on litter size at day 74 of gestation

\begin{tabular}{|c|c|c|c|c|c|c|c|}
\hline Treatment & $n$ & 0 & $I$ & $\begin{array}{c}\text { Litter size } \\
2\end{array}$ & 3 & 4 & $\begin{array}{l}\text { Fetuses per } \\
\text { pregnancy }\end{array}$ \\
\hline Control & 48 & $\begin{array}{c}6 \\
(12.5)\end{array}$ & $\begin{array}{l}11 \\
(22.9)\end{array}$ & $\begin{array}{c}22 \\
(45.8)\end{array}$ & $\begin{array}{c}8 \\
(16.7)\end{array}$ & $\begin{array}{l}1 \\
(2.1)\end{array}$ & 1.98 \\
\hline $\begin{array}{l}\text { Progesterone } \\
\text { days } 1-3\end{array}$ & 49 & $\begin{array}{l}18 \\
(36.7)\end{array}$ & $\begin{array}{l}16 \\
(32.7)\end{array}$ & $\begin{array}{l}11 \\
(22.4)\end{array}$ & $\begin{array}{l}3 \\
(6.1)\end{array}$ & $\begin{array}{l}1 \\
(2.0)\end{array}$ & 1.65 \\
\hline days $1-6$ & 48 & $\begin{array}{c}16 \\
(33.3)\end{array}$ & $\begin{array}{c}14 \\
(29.2)\end{array}$ & $\begin{array}{c}13 \\
(27.1)\end{array}$ & $\begin{array}{c}5 \\
(10.4)\end{array}$ & $\begin{array}{c}0 \\
(0.0)\end{array}$ & 1.72 \\
\hline days 3-6 & 46 & $\begin{array}{c}8 \\
(17.4)\end{array}$ & $\begin{array}{l}10 \\
(21.7)\end{array}$ & $\begin{array}{l}20 \\
(43.5)\end{array}$ & $\begin{array}{c}6 \\
(13.0)\end{array}$ & $\begin{array}{c}2 \\
(4.3)\end{array}$ & 2.00 \\
\hline
\end{tabular}

Values in parentheses are percentages.

Table 4. Main effects of progesterone treatment given to ewes on days I-3 of pregnancy on fetal mass and crown-rump length. Zygotes were transferred to the oviducts of initial recipients on day 1 and transferred on day 3 to the uterus of final recipients

\begin{tabular}{lccc}
\hline Treatment & $\begin{array}{c}\text { Number of } \\
\text { fetuses }\end{array}$ & $\begin{array}{c}\text { Fetal mass } \\
(\mathrm{g})\end{array}$ & $\begin{array}{c}\text { Crown-rump length } \\
\text { (mm) }\end{array}$ \\
\hline $\begin{array}{l}\text { Initial recipient } \\
\quad \text { Control }\end{array}$ & 42 & $258.9 \pm 5.0^{\mathrm{a}}$ & $229.2 \pm 2.7^{\mathrm{a}}$ \\
$\quad$ Progesterone & 52 & $262.8 \pm 4.6^{\mathrm{ac}}$ & $234.5 \pm 2.5^{\mathrm{a}}$ \\
$\quad \begin{array}{l}\text { Progesterone plus oviduct ligature } \\
\text { Final recipient }\end{array}$ & 34 & $278.4 \pm 6.9^{\mathrm{bc}}$ & $238.8 \pm 3.7^{\mathrm{a}}$ \\
$\quad$ Control & & & \\
$\quad$ Progesterone & 89 & $257.3 \pm 3.4^{\mathrm{a}}$ & $233.7 \pm 1.9^{\mathrm{a}}$ \\
\hline
\end{tabular}

Values are least-squares means \pm SEM.

Means within columns and main effects with different superscripts are significantly different $(P<0.05)$.

Table 5. Effect of progesterone treatment during days $1-3$ of pregnancy in ewes on cleavage and on the number of blastomeres per embryo on day 3

\begin{tabular}{|c|c|c|c|c|c|}
\hline \multirow[b]{2}{*}{ Initial recipient } & \multirow{2}{*}{$\begin{array}{l}\text { Number } \\
\text { cleaved }\end{array}$} & \multicolumn{4}{|c|}{ Blastomeres per embryo } \\
\hline & & $2-3$ & $4-7$ & $8-15$ & $\geq 16$ \\
\hline Control & $\begin{array}{c}176 / 230^{\mathrm{a}} \\
(76.5)\end{array}$ & $\begin{array}{c}5 \\
(2.8)\end{array}$ & $\begin{array}{c}6 \\
(3.4)\end{array}$ & $\begin{array}{l}116 \\
(65.9)\end{array}$ & $\begin{array}{l}49 \\
(27.8)\end{array}$ \\
\hline Progesterone & $\begin{array}{c}138 / 216^{\mathrm{b}} \\
(63.9)\end{array}$ & $\begin{array}{c}0 \\
(0.0)\end{array}$ & $\begin{array}{c}6 \\
(4.3)\end{array}$ & $\begin{array}{l}54 \\
(39.1)\end{array}$ & $\begin{array}{l}78 \\
(56.5)\end{array}$ \\
\hline Progesterone plus oviduct ligation & $\begin{array}{c}155 / 207^{\mathrm{a}} \\
(74.9)\end{array}$ & $\begin{array}{l}18 \\
(11.6)\end{array}$ & $\begin{array}{l}39 \\
(25.2)\end{array}$ & $\begin{array}{l}70 \\
(45.2)\end{array}$ & $\begin{array}{l}28 \\
(18.1)\end{array}$ \\
\hline
\end{tabular}

Values with different superscripts are significantly different $(P<0.05)$.

Values in parentheses are percentages.

survival after two transfers was low $(<37 \%)$, they found that surviving fetuses showed greater crown-rump length at day 37 of pregnancy compared with control fetuses.

Increased fetal growth resulting from exposure to progesterone at an early age may not necessarily be mediated through specific uterine factors, as embryos that were retained in the oviducts of initial recipients by ligation and transferred to final recipients that were not treated with progesterone were significantly heavier on day 76 than the control group. This finding is in contrast with other data from Expt 2 which indicated that enhanced fetal growth occurred only when embryos were transferred to final recipients that had been treated with progesterone on days 1-3. Ligation of the oviduct between days $I$ and 3 resulted in an increased retention of 
Table 6. The effect of progesterone given to ewes on days 1-3 of pregnancy on pregnancy rate and litter size at day 76 . Zygotes were transferred to the oviducts of initial recipients on day 1 and then transferred to final recipients on day 3

\begin{tabular}{|c|c|c|c|c|}
\hline & \multicolumn{2}{|c|}{$\begin{array}{l}\text { Pregnancy rate }(\%) \\
\text { Final recipient }\end{array}$} & \multicolumn{2}{|c|}{$\begin{array}{l}\text { Fetuses per pregnancy } \\
\text { Final recipient }\end{array}$} \\
\hline & Control & Progesterone & Control & Progesterone \\
\hline \multicolumn{5}{|l|}{ Initial recipient } \\
\hline Control & $\begin{array}{c}42.1 \\
(16 / 38)\end{array}$ & $\begin{array}{c}34.1 \\
(14 / 41)\end{array}$ & $\begin{array}{c}1.50 \\
(24 / 16)\end{array}$ & $\begin{array}{c}1.29 \\
(18 / 14)\end{array}$ \\
\hline Progesterone & $\begin{array}{c}66.7 \\
(24 / 36)\end{array}$ & $\begin{array}{c}28.6 \\
(10 / 35)\end{array}$ & $\begin{array}{c}1.54 \\
(37 / 24)\end{array}$ & $\begin{array}{c}1.50 \\
(15 / 10)\end{array}$ \\
\hline Progesterone plus oviduct ligation & $\begin{array}{c}48.6 \\
(17 / 35)\end{array}$ & $\begin{array}{l}21.6 \\
(8 / 37)\end{array}$ & $\begin{array}{c}1.53 \\
(26 / 17)\end{array}$ & $\begin{array}{l}1.00 \\
(8 / 8)\end{array}$ \\
\hline
\end{tabular}

The number of ewes pregnant of those treated and the number of fetuses of pregnant ewes are shown in parentheses.

oviductal fluid, the creation of an atypical environment as indicated by the presence of large numbers of macrophages on recovered embryos and the production of embryos with fewer blastomeres than normal. The latter consequence may be particularly relevant, as retarded development would probably increase the degree of asynchrony upon the transfer of these embryos to final recipients. It is of interest that the increased fetal growth reported by Wilmut and Sales (1981) after asynchronous transfer on day 3 depended on the developmental stage of the embryo, with eight-cell embryos (rather than morulae and blastocysts) growing faster than control embryos.

It is also possible that progesterone treatment resulted in a selection of embryos that had an inherent capacity to develop faster or could respond more quickly to the progesteronemediated changes in the uterine milieu. In Expt 1 , the largest responses in fetal growth were obtained in the two groups in which progesterone treatment began on day 1. Embryo survival in both of these groups was significantly reduced. However, when progesterone treatment began on day 3, fetal growth improved, but without an associated decrease in embryo survival. It may be significant that the increase in fetal mass in this group was less than that obtained in the two groups in which progesterone treatment began on day 1 . Furthermore, results from Expt 2 indicate that increased embryo loss owing to progesterone treatment occurred after day 3 and resulted from ewes losing both embryos, as indicated by a reduction in pregnancy rate, rather than from ewes suffering partial loss. Ashworth et al. (1989) observed that embryo survival was associated with large variations in progesterone secretion during the first few days after ovulation and that high endogenous concentrations were related to improved survival. In the present study, progesterone concentrations in plasma of ewes treated with progesterone on days $1-3$ were two to three times higher than endogenous values. It is possible, therefore, as suggested by Ashworth et al. (1989), that increased embryo mortality may have been due to the influence of progesterone on the timing of uterine changes and the subsequent development of an asynchrony between the embryo and uterine environment.

In conclusion, the results of this study indicate that fetal growth is enhanced when ewes are supplemented with progesterone during the first 3 days of pregnancy. This effect is mediated after 3 days unless the oviducts of ewes are ligated, in which case, the effect is more immediate. These results therefore provide further evidence that changes to the environment of the early embryo can influence subsequent development.

We thank T. Heard, K. Cockrum, J. Evans, C. Bee for skilled technical support, R. Ashman for conducting surgery, M. Guerin for performing the progesterone assays, R. Ponzoni for help with statistical analysis and $\mathrm{H}$. Graetz for preparation of the manuscript.

\section{References}

Ashworth CJ and Bazer FW (1989) Changes in ovine conceptus and endometrial function following asynchronous embryo transfer or administration of progesterone Biology of Reproduction 40 425-433

Ashworth CJ, Sales DI and Wilmut I (1989) Evidence of an association between the survival of embryos and the periovulatory plasma progesterone concentration in the ewe Journal of Reproduction and Fertility 87 23-32

Chang MC (1950) Development and fate of transferred rabbit ova or blastocysts in relation to the ovulation time of recipients Journal of Experimental Zoology 114 197-216

Crisman RO, McDonald LE and Thompson FN (1980) Effects of progesterone or estradiol on uterine tubal transport of ova in the cow Theriogenology 13 141-154

Day BN and Polge C (1968) Effects of progesterone on fertilisation and egg transport in the pig Journal of Reproduction and Fertility 17 227-230

Garrett JE, Geisert RD, Zavy MT and Morgan GL (1988) Evidence for maternal regulation of early conceptus growth and development in beef cattle Journal of Reproduction and Fertility 84 437-446

Geisert RD, Lee CY, Simmen FA, Zavy MT, Fliss AI, Bazer FW and Simmen RCM (1991) Expression of mRNAs encoding insulin-like growth factor-I, -II and insulin-like growth factor binding protein-2 in bovine endometrium during the estrous cycle and early pregnancy Biology of Reproduction 45 975-983

Hochstrasser DF, Patchornik A and Merril CR (1988) Development of polyacrylamide gels that improve the separation of proteins and their detection by silver staining Analytical Biochemistry 173 412-423

Hunter RHF (1980) Function of the Fallopian tubes in relation to gametes and embryos. In Physiology and Technology of Reproduction in Female Domestic Animals pp 145-183 Ed. RHF Hunter. Academic Press, London

Killeen ID and Caffery GJ (1982) Uterine insemination of ewes with the aid of a laparoscope Australian Veterinary Journal $\mathbf{5 9} 95$

Laemmli UK (1970) Cleavage of structural proteins during the assembly of the head of bacteriophage T4 Nature $227680-685$

Moore NW and Shelton JN (1964) Egg transfer in sheep: effect of degree of synchronisation between donor and recipient, age of egg, and site of transfer on the survival of transferred eggs Journal of Reproduction and Fertility 7 $145-152$ 
Moore NW, Miller BG and Trappl MN (1983) Transport and development of embryos transferred to the oviducts and uteri of entire and ovariectomized ewes Journal of Reproduction and Fertility 68 129-135

Roberts RM and Bazer FW (1988) The functions of uterine secretions Joumal of Reproduction and Fertility 82 875-892

Robinson TJ (1951) The control of fertility in sheep. The augmentation of fertility by gonadotrophin treatment of the ewe in the normal breeding season Joumal of Agricultural Science 41 6-63

Stanish WM and Sall JP (1985) The CATMOD procedure. In SAS User's Guide, Statistics pp 171-253. SAS Institute Inc., Cary, NC

Spector PC, Goodnight JH, Sall JP and Sarle WS (1985) The GLM procedure. In SAS User's Guide, Statistics pp 433-506. SAS Institute Inc., Cary, NC

Walker SK, Smith DH and Seamark RF (1986) Timing of multiple ovulations in the ewe after treatment with FSH or PMSG with and without GnRH Journal of Reproduction and Fertility 77 135-142
Walker SK, Smith DH, Godfrey B and Seamark RF (1989) Time of ovulation in the South Australian Merino ewe following synchronization of estrus. 1 . Variation within and between flocks Theriogenology 31 545-553

Walker SK, Heard TM and Seamark RF (1992a) In vitro culture of sheep embryos without co-culture: successes and perspectives Theriogenology 37 111-126

Walker SK, Heard TM, Bee CA, Frensham AB, Warnes DM and Seamark RF (1992b) Culture of embryos of farm animals. In Embryonic Development and Manipulation in Animal Production pp 77-92 Eds A Lauria and F Gandolfi. Portland Press Ltd, London

Willadsen SM, Janzen RE, McAlister RJ, Shea BF, Hamilton G and McDermand D (1991) The viability of late morulae and blastocysts produced by nuclear transplantation in cattle Theriogenology 35 161-170

Wilmut I and Sales DI (1981) Effect of an asynchronous environment on embryonic development in sheep Journal of Reproduction and Fertility 61 $179-184$ 